\title{
EFFECTS OF TRANEXAMIC ACID ADMINISTRATION ON RECOVERY AFTER UNILATERAL TOTAL KNEE ARTHROPLASTY
}

\author{
QIANG LI, JUN XIAO*, HAILUN ZHU, SHIXIONG ZHENG, ZHANJUN SHI \\ Department of Orthopaedic Surgery, Nanfang Hospital, Southern Medical University, Guangzhou, Guangdong Province \\ 510515, PR China
}

*corresponding author:xjxiaojun01@163.com

Manuscript received: December 2017

\begin{abstract}
Knee arthroplasty (TKA) plays an important role in the treatment of knee osteoarthritis (KOA). This study aimed to investigate the impact of tranexamic acid (TXA) administration on the amount of bleeding and knee function improvement in unilateral total knee arthroplasty (TKA). One hundred and two patients who underwent primary unilateral TKA surgery in Nanfang Hospital, Southern Medical University, Guangzhou, China from June 2015 to May 2017 were divided into three groups: group A was intravenously and intraarticularly injected tranexamic acid, group B was injected with tranexamic acid in the joint cavity and group $\mathrm{C}$ was injected intravenously and intraarticularly with saline solution, 34 patients in each group. After losses to follow-up we ended with 91 patients: 31 cases in group A, 28 cases in group B, 32 in group C. The demographic and biochemical parameters of the three groups at the baseline were analysed as: age, gender, body mass index, preoperative haemoglobin, preoperative haematocrit, preoperative D-dimer (DD), preoperative knee mobility, Knee Society Score (KSS) function scores, operative time and incision length. All these variables were not statistically significant different between the groups $(\mathrm{p}>0.05)$. Changes in body temperature, total blood loss, visible blood loss, occult blood loss, D- dimer, pain degree, swelling degree and mobility of the knee joint were compared after surgery. The KSS, Lysholm and Hospital for Special Surgery (HSS) scores of the knee joint were measured three and six months after the surgery. The KSS function score, HSS score and Lysholm score of knee joint three months after operation were statistically significant different $(p<$ 0.05). The scores of $A$ and $B$ group were higher than those of group $C$, but there was no statistically significant difference between group A and group B ( $p>0.05)$. After six months follow-up, in the knee mobility and KSS function scores of the three groups was no difference $(\mathrm{p}>0.05)$. The injection of tranexamic acid in the venous joint cavity can effectively reduce the amount of red blood cells after TKA surgery, and it can reduce the possibility of patients undergoing allogeneic red blood cells after surgery.
\end{abstract}

\section{Rezumat}

Artroplastia de genunchi (TKA) joacă un rol important în tratamentul osteoartritelor genunchiului (KOA). Scopul prezentului studiu este de a analiza efectul administrării acidului traxenamic (TXA) asupra sângerării și a îmbunătățirii funcției genunchiului după artroplastia unilaterală totală de genunchi. O sută doi pacienți care au fost supuşi TKA primare unilaterale în perioada Iunie 2015 - Mai 2017 în spitalul Nanfang, Universitatea de Medicină de Sud din Guangzhou, China, au fost împărțiți în trei grupuri: grupul A căruia i s-a administrat intravenos și intraarticular acid tranexamic, grupul B la care s-a administrat intraarticular acid tranexamic și grupul C la care s-a administrat intravenos și intraarticular ser fiziologic, 34 de pacienți în fiecare grup. După ce unii pacienți s-au pierdut pe parcursul studiului, au rămas 91 pacienți: 31 cazuri în grupul A, 28 cazuri în grupuil B și 32 în grupul C. Parametrii demografici și biochimici ai celor introduși în studiu au fost analizați înainte de începerea studiului, astfel: vârsta, sexul, indicele de masă corporală, nivelul hemoglobinei, al hematocritului, al dimerului-D, al mobilității genunchiului, al scorului KSS (Knee Society Score), timpul operației și lungimea inciziei. Toate aceste variabile nu au prezentat diferențe semnificativ statistice între cele trei grupuri (p > 0,05). După operație au fost evaluate modificările cu privire la temperatura corpului, pierderea totală de sânge, pierderea vizibilă de sânge, pierderea ocultă de sânge, dimerul-D, gradul de durere, gradul de inflamație, precum și mobilitatea articulației genunchiului. Scorurile KSS, Lysholm și HSS (Hospital for Special Surgery) ale articulației genunchiului au fost măsurate la trei şi șase luni după operație. Scorurile KSS, Lysholm și ale articulației genunchiului la trei luni după operație au prezentat diferențe semnificativ statistice între grupuri $(\mathrm{p}<0,05)$. Scorurile grupurilor A și B au fost mai crescute comparativ cu grupul $\mathrm{C}$, dar nu s-au semnalat diferențe semnificative între scorurile grupului A și B $(p>0,05)$. La șase luni de la operaţie nu s-au semnalat diferențe în ceea ce privește mobilitatea genunchiului și scorul KSS între cele trei grupuri $(p>0,05)$.

Keywords: tranexamic acid, total knee arthroplasty, knee joint function

\section{Introduction}

Knee osteoarthritis (KOA) is a degenerative disease more common in older people. The symptoms include knee pain, knee swelling and snapping. In early stages, oral glucosamine or chondroitin sulphate and intra-articular injection of hyaluronic acid were used for conservative treatment $[1,2]$. 
FARMACIA, 2018, Vol. 66, 4

With the increasing population over 65 years, the number of osteoarthritis patients increased significantly. Studies have been showed that if the degeneration of articular cartilage occurs, the process cannot be reversed. Early conservative treatment can help patients alleviate joint pain. However, with age the disease develops and final stages of KOA are characterized by joint disability. At this stage drug treatment cannot effectively improve the quality of life in patients with bone and joint knee osteoarthritis [3]. Thus, the patient will have to undergo surgical treatment in order to relieve pain and rebuild joint function.

As the ultimate treatment modality, prosthetic replacement is the main way to treat middle and late stage osteoarthritis, which drastically alleviates the pain caused by KOA. There is growing evidence that total knee arthroplasty (TKA) plays an important role in the treatment of KOA [4]. According to statistics, about $90 \%$ of KOA patients can relieve pain and reconstruct joint function through TKA $[5,6]$. It is well known that surgery is probable to cause blood loss. The knee joint is the largest synovial joint in the whole body, and the circulation of blood is very rich. It is the anatomic basis of the large blood loss during the perioperative period of knee replacement. The initial surgery need to clean up more synovial and osteophyte, and multi-faceted osteotomy and dressing on femur, tibia and tibial are carried out. The operation is traumatic and the amount of bone is large. The amount of bleeding is often increased after the replacement of knee joint, which influences the effect of joint replacement directly or indirectly. Tourniquet is often used during surgery to keep the field clear, but even after a short period of use, the fibrinolytic system is activated. The balance between intravascular coagulation and fibrinolysis is disrupted, leading to continued loss of blood after surgery [7]. It is estimated that postoperative blood loss in patients undergoing primary knee arthroplasty is $500 \sim 2000 \mathrm{~mL}$, and haemoglobin decrease to about $30 \mathrm{~g} / \mathrm{L}$ after surgery. In addition, people who received TKA were mostly elderly patients with poor hematopoietic functioning, weak ability to correct anaemia, and relatively slow healing of the incision. The postoperative blood transfusion rate is higher, about $15 \% \sim 62 \%$ [8-10]. Therefore, reducing the postoperative bleeding is a major concern.

In recent years, tranexamic acid (TXA) is widely used as a fibrinolysis inhibitor to control blood loss during perioperative period of TKA and improve recovery. It is a synthetic fibrinolytic protein derivative that is strongly adsorbed on the site of lysine binding sites on plasmin and plasminogen. It inhibits plasmin and plasminogen binding to fibrin, thereby strongly inhibiting plasmin breakdown by plasmin and reducing bleeding [11]. Currently, evidences on the haemostatic effects of tranexamic acid are reported after different ways of administration [12-14]. The aim of this study was to assess the impact of tranexamic acid (TXA) administration in the joint cavity on the amount of bleeding and knee function improvement in unilateral TKA.

\section{Materials and Methods}

\section{Patients}

A total of 102 patients admitted to Nanfang Hospital, Southern Medical University, Guangzhou, China between June 2015 and May 2017 were divided into three groups of 34 patients. In group A, 15 minutes before surgery, the tranexamic acid injection was dissolved in $100 \mathrm{~mL} 0.9 \%$ sodium chloride and administered intravenous in a dose of $15 \mathrm{mg} / \mathrm{kg}$. At the same time, after closing the joint cavity, $1 \mathrm{~g}$ TXA was dissolved in $20 \mathrm{~mL} 0.9 \%$ sodium chloride injection joint for intra-cavitary injection). In group B, 15 minutes before surgery, $100 \mathrm{~mL} 0.9 \%$ sodium chloride was injected intravenously. At the same time, after closing the joint cavity, $1 \mathrm{~g}$ TXA was dissolved in $20 \mathrm{~mL} 0.9 \%$ sodium chloride for intra-articular injection. In group C, 15 minutes before surgery, $100 \mathrm{~mL} 0.9 \%$ sodium chloride was injected intravenously and $20 \mathrm{~mL}$ saline was injected intra-articular after closing the joint cavity. After operation, 11 patients were lost to visit, including 3 cases in group A, 6 cases in group B, 2 cases in group $\mathrm{C}$, respectively. In the final study, 91 patients were enrolled in this study: 31 cases in group A, 28 cases in group B, 32 in group C.

The study was approved by the Ethics Committee of Nanfang Hospital, Southern Medical University, Guangzhou, China and all patients had signed the informed consent.

\section{Inclusion criteria}

In the study were included patients diagnosed preoperatively with KOA: patients who suffered from prolonged and repeated knee pain and have been treated with active nonoperative treatment, patients who had undergone unilateral knee replacement surgery and had no previous history of trauma and surgery after initial surgery, patients who underwent routine X-Ray and magnetic resonance imaging before surgery, as well as suffered from joint space narrowing, severe bone abrasion or defect, varus deformity of lower limb and deformity, patients who had been treated conservatively for 6 months without symptoms, patients who are mentally normal and able to follow the advice of a rehabilitation physician after TKA surgery, as well as actively cooperate with TKA after joint functional exercises. 
FARMACIA, 2018, Vol. 66, 4

Exclusion criteria

Patients who suffered from infectious diseases recently in other areas of body or patients with a recent or local suppurative infection healed, patients who suffered from cerebral infarction or knee extensor dysfunction due to poliomyelitis sequelae, patients who had hyperextension and knee function loss led by decreased muscular strength without the feeling of knee joint pain, non KOA patients, patients who had abnormal coagulation, moderate and severe anaemia, as well as malignant tumour, also with the history of vascular thrombosis such as cerebral infarction and myocardial infarction, patients with contraindications to TXA or low molecular heparin, calcium, and Shaaban, while they are taking anticoagulant drugs for a long time and medicines with the function of activating blood stasis, patients with poor general conditions, suffering from severe comorbidities and with poor cognitive function, which can affect the outcome of the postoperative treatment.

\section{Rejection criteria}

Patients who were not treated or did not exercise according to the established rehabilitation plans; patients who were unable to follow-up and who had not been examined in accordance with the prescribed time; patients who suffered from bleeding by nonoperative factors during the follow-up; patients who died during the follow-up period.

Follow-up method

The follow-up period was 6 months.

Imaging examination

All patients underwent the routine examination of standing position of the knee joint and the lateral phase of the knee. The anatomical axis and mechanical axis of the femur and tibia were determined by the full-length leg X-ray before operation, so that the mechanical axis of the lower limb was located at the center of the knee prosthesis. If the joint bone defect was obvious, routine three- dimensional computer tomograph (CT) examination of the knee was be performed to determine the extent of the bone defect and prepare for the preoperative planning.

Laboratory examination

The routine examination included Erythrocyte Sedimentation Rate (ESR), erythrocyte ratio/ haematocrit (HCT), rheumatoid factor coagulation tests: Thrombo-plastin Time (PT) and Activated Partial Thrombo-plastin Time (APTT). Laboratory tests excluded other articular diseases like rheumatoid arthritis, haemophilia arthritis, gout, Kashin-Beck disease.

The blood loss was examined as follows: total red cell loss, the red cell loss after operation, the amount of occult red blood cell loss. In addition, the observation included Hospital for Special Surgery (HSS) score and postoperative pain score. blood loss $=B V \times\left(\right.$ Hct $\left._{\text {preop }}-H c t_{\text {dayXpostop }}\right)$

In the formula, $\mathrm{BV}$ is blood volume, $\mathrm{Hct}_{\text {preop }}$ is the preoperative haematocrit, Hct $_{\text {dayXpostop }}$ is the haematocrit at day $\mathrm{X}$ after surgery, $\mathrm{Vt}$ is the number of suspended red blood cells.

The Nadler blood volume was calculated as follows:

blood volume $=k_{1} \times$ height $^{3}(\mathrm{~m})+k_{2} \times$ weight $(\mathrm{kg})+k_{3}$ The values of $\mathrm{k} 1, \mathrm{k} 2$ and $\mathrm{k} 3$ were for the male patients $0.3669,0.03219$ and 0.6041 , respectively, and for the female patients were $0.3561,0.03308$ and 0.183333 respectively.

The curative effect indexes included total red cell loss, erythrocyte loss and occult red blood cell loss after operation. The patient's blood volume and total red cell loss were calculated according to the Mercuriali's method as described below (total red cell loss, postoperative red cell loss, hidden red cell loss). Vt is the amount of blood transfusion. Blood routine examination was performed to observe the healing of the incision, whether there was swelling or necrosis of the skin border.

$$
\begin{gathered}
\text { Total red cell loss }=P V B \times\left(H C T_{\text {preoperative }}-H C T_{\text {postoperative }}\right)+V t \\
\text { Postoperative red cell loss }=\text { postoperative wound drainage } \times H C T_{\text {pre }}, H C T_{\text {post }} \text { average } \\
\text { Hidden red cell loss }=\text { total erythrocyte loss }- \text { red blood cell loss after operation }+ \text { cell input }
\end{gathered}
$$

\section{Pain degree evaluation}

For the pain degree evaluation Visual Analogue Scale (VAS), the Numerical Rating Scale (NRS), or Verbal Rating Scale (VRS) were used.

Statistical analysis method

Data was expressed by mean + standard deviation. Microsoft Excel (Microsoft Corporation, Redmond, USA) was used for data collection and analysis. SPSS16.0 software was used. The enumeration data was checked by chi square test and the continuous data, by one-way ANOVA between the groups, and probability $\mathrm{p}<0.05$ was considered statistically significant.

\section{Results and Discussion}

Comparison of age, sex, BMI and preoperative examination

There were no statistically significant differences in age, sex, BMI, preoperative examination (including the indicators of haemoglobin, haematocrit, D-, two polymers, and blood coagulation), preoperative physical examination, knee mobility, and KSS function score in each group (Table I, Figure 1 and Figure 2). 
Table I

Demographic data of the patients

\begin{tabular}{ccccc}
\hline & Age (Years) & $\begin{array}{c}\text { Gender } \\
(\text { Female } / \text { Male })\end{array}$ & $\begin{array}{c}\text { Body mass index } \\
\left(\mathrm{Kg} / \mathrm{m}^{2}\right)\end{array}$ & Side (Left/Right) \\
\hline $\mathrm{A}(\mathrm{n}=31)$ & $62.7 \pm 1.1$ & $15 / 16$ & $24.9 \pm 1.3$ & $17 / 14$ \\
$\mathrm{~B}(\mathrm{n}=28)$ & $63.0 \pm 0.8$ & $13 / 15$ & $25.3 \pm 1.1$ & $15 / 13$ \\
$\mathrm{C}(\mathrm{n}=32)$ & $62.8 \pm 1.0$ & $15 / 17$ & $25.1 \pm 1.4$ & $16 / 16$ \\
$\mathrm{p}$ & 0.495 & 0.987 & 0.527 & 0.924 \\
\hline
\end{tabular}

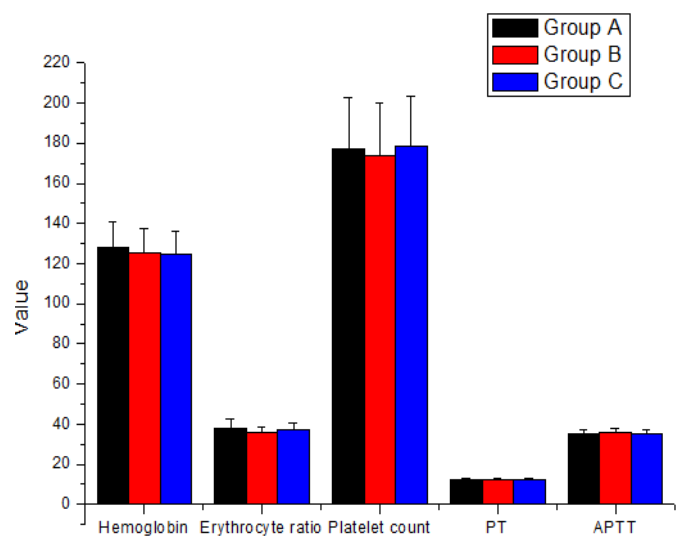

Figure 1.

Comparison of preoperative routine blood and blood coagulation test

(PT - Thromboplastin Time; APTT - Activated Partial Thromboplastin Time)

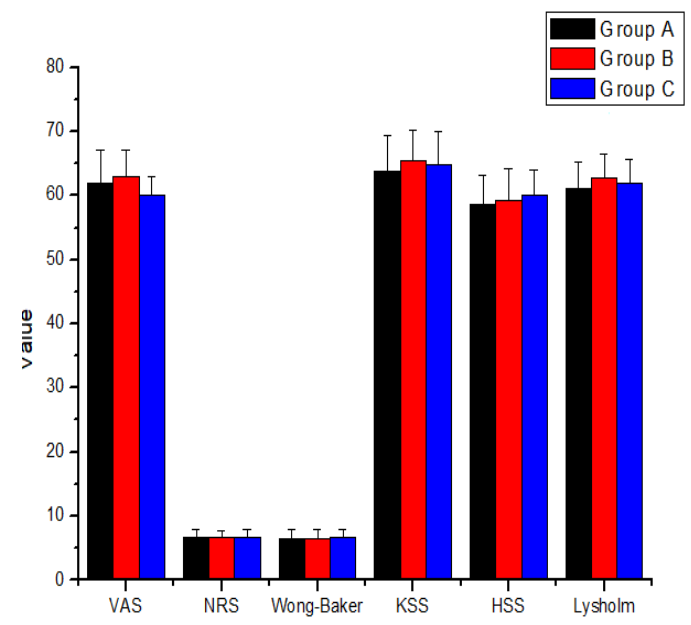

Figure 2.

Preoperative knee pain and function score (VAS - Visual Analogue Scale; NRS - Numerical Rating Scale; KSS - Knee Society Score; HSS - Hospital for Special Surgery)

Comparison of operating time, incision length, and intraoperative bleeding

There were no statistical significance differences in the length of operation, the size of the incision and the amount of blood in the operation ( $p>0.05$, shown in Figure 3).

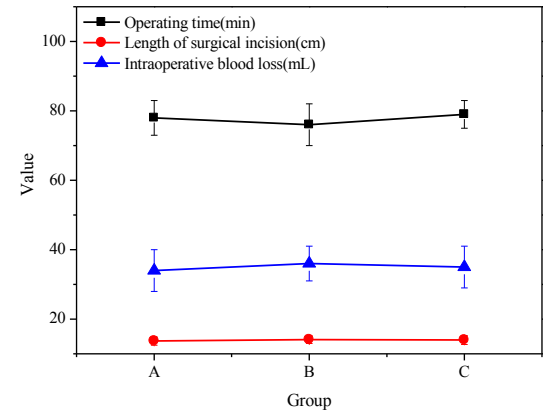

Figure 3.

Comparison of intraoperative parameters between the three groups

Comparison of postoperative blood loss

All the incisions were healed in I stage. There were no complications such as DVT, infection and nerve and blood vessel injury. Postoperative loss of blood comparison is show in Figure 4.

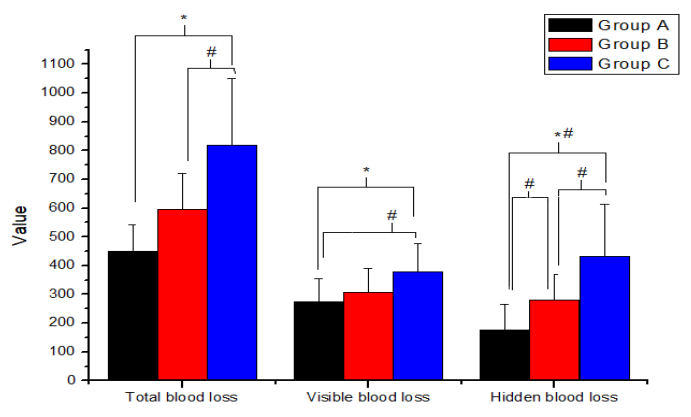

Figure 4.

Comparison of postoperative blood loss between the three groups

(* indicates that the differences between 3 groups is significant $(\mathrm{p}<0.05)$; \# represents the comparison between 2 groups is significant $(\mathrm{p}<0.05))$

It was found that postoperative blood loss, measured as total blood loss, visible blood loss was significantly different between groups: groups A versus group $\mathrm{C}$, and also group $\mathrm{B}$ versus group $\mathrm{C}(\mathrm{p}$ $<0.05)$.

There were no statistically significant differences in the parameters such as the amount of bleeding calculated during surgery and the length of the surgical incision measured when the knee flexion was $90^{\circ}(\mathrm{p}>0.05)$. 
A comparison of knee pain improvement

After the TKA operation, patients felt pain at the incision of the knee, mainly caused by swelling and accumulation of blood in the knee joint. Postoperation pain can be relieved only a week after operation. The knee joint hematoma will appear with knee joint ache, affects the knee joint function and exercise. Levels of knee pain were compared with Wong-Baker Faces Pain Rating Scale and results are shown in Figure 5.

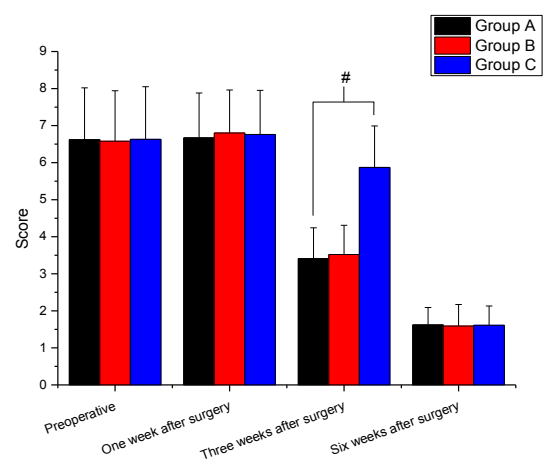

Figure 5.

Comparison of postoperative knee pain score in patients (\# represents $\mathrm{p}<0.01$ )

There was no significant difference in preoperative pain scores among the three groups. Affected by the incision pain, there was no difference in knee pain among the three groups after one week of knee pain after TKA surgery $(p>0.05)$. The pain score of the $\mathrm{C}$ group was higher than that of the A group and the B group at three weeks after operation, and the difference was statistically significant $(\mathrm{p}<0.01)$. There was no statistical significance in the HSS score between the A group and the B group ( $p>$ $0.05)$. The knee pain score of the three groups had no statistical significance after six weeks $(\mathrm{p}>0.05)$, which indicated that patients with TXA had less knee pain in the short term than the untreated patients. In the long term, the pain of knee joint was obviously relieved, and there was no statistical difference between the groups $(\mathrm{p}>0.05)$.

Comparison of knee function in patients after operation

There was no significant difference in preoperative HSS score among the three groups (shown in Figure 6). Comparison of the knee function, three months after TKA surgery, showed that the HSS score of group C was statistically significantly lower than that of the first two groups $(p=0.032)$. The HSS scores of the former two groups were not statistically significant different $(p>0.05)$. The HSS score of the three groups was not statistically significant $(\mathrm{p}>0.05)$ at sixth months follow-up after the operation. In conclusion, the short-term knee function of patients with TXA is better than that in the untreated patients. But in the long term, there was no statistically significant difference in knee function $(\mathrm{p}>0.05)$.

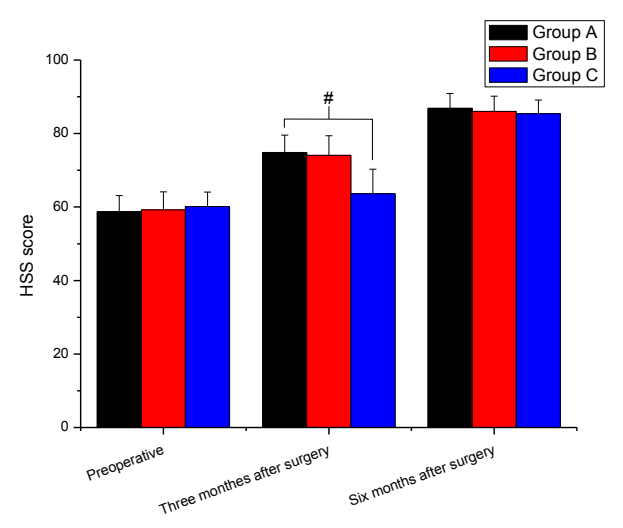

Figure 6.

Comparison of HSS score in patients with knee joint replacement (\# represents $\mathrm{p}<0.05$ )

TKA is a potent treatment with satisfactory results and satisfactory functional recovery for patients with advanced KOA lesions who did not showed satisfactory results after general treatment or medication. However, the large incision, a large amount of bone and the use of the tourniquet activate the local fibrinolysis system, which result in considerable perioperative blood loss. Therefore, postoperative haemostasis is further affected by joint surgery. The TKA operation can reduce the bleeding of the bone surface during osteotomy with the tourniquet. Because the vein of the lower extremity is under hypoxia conditions, the endothelial cells release large amounts of vasodilator material. The latter promotes the release of plasminogen activator by the vascular endothelium. The fibrinolytic reaction is promoted, thus the amount of bleeding increases greatly after the tourniquet is loosened. In clinical practice, joint surgeons use tourniquet in TKA surgery. This can reduce intraoperative blood loss, but also clear vision and facilitate the operation. The dried bone cement interface is also beneficial for prosthesis fixation [15-17]. In the experimental design, in order to control the operation time within ninety minutes, the whole tourniquet technique is adopted. At the same time, the pressure of the tourniquet is set at $260 \mathrm{mmHg}$ and the use time is controlled within $90 \min$ [18-21].

TXA is becoming more and more widely used in clinical practice. Through observational studies, researchers found that TXA significantly reduced blood loss after TKA and decreased the rate of red blood cell transfusion without increasing the risk of developing DVT [22-25]. Therefore, during design 
FARMACIA, 2018, Vol. 66, 4

trials, TXA was chosen for the patients before the tourniquet was inflated, and $15 \mathrm{mg} / \mathrm{kg}$ TXT is dripping at $15 \mathrm{~min}$ before surgery. In this study, a single injection of the knee joint was compared. The local high concentration of tranexamic acid solution can be more direct, quick and simple to deliver the drug to the articular cavity. The local drug concentration is higher [26]. In the intraarticular injection, the amount of injection was $1 \mathrm{~g}$, and the time of the drainage tube clamping was $2 \mathrm{~h}$. In this study, the combined use and local use of TXA were effective in reducing postoperative blood loss, and there was a statistically significant difference in total red cell loss $(p<0.05)$. Either combined use or local use, the number of suspended red blood cells at the end of the operation decreased significantly. However, the amount of bleeding in patients without TXA was significantly increased in comparison with the use of TXA in the A and B groups.

\section{Conclusions}

This is a prospective randomized controlled study that compares several methods using tranexamic acid. The results confirmed that the intravenous and local application of tranexamic acid can effectively reduce the TKA postoperative loss of red blood cells and reduce the possibility of postoperative patients with allogeneic red blood cells input. Based on these findings, it may be considered that the intravenous or local use of tranexamic acid during surgery should be recommended as a safe and effective way to reduce blood loss. However, a large sample and multicentre study is needed to provide guidance for the clinical aspects.

\section{References}

1. Lowry V, Ouellet P, Vendittoli P-A, Carlesso LC, Wideman TH, Desmeules F, Determinants of pain, disability, health-related quality of life and physical performance in patients with knee osteoarthritis awaiting total joint arthroplasty. Disabil Rehabil., 2017: 1-11.

2. Bumbea AM, Mușetescu AE, Albulescu DM, Dumitrașcu RC, Bumbea BS, Popescu D, Albu CV, The occurrence risk of demyelinating lesions in patients with rheumatoid arthritis and anti-TNF $\alpha$ biological therapy. Farmacia, 2017; 65(6): 917-922.

3. Martel-Pelletier J, Raynauld JP, Mineau F, Abram F, Paiement P, Delorme P, Pelletier JP, Levels of serum bio-markers from a two-year multicentre trial are associated with treatment response on knee osteoarthritis cartilage loss as assessed by magnetic resonance imaging: An exploratory study. Arthritis Res Ther., 2017; 19: 1-11.

4. Kurata K, Matsushita J, Furuno A, Fujino J, Takamatsu H, Assessment of thermal damage in total knee arthroplasty using an osteocyte injury model. J Orthop Res., 2017; 35(12): 2799-2807
5. Xiang $\mathrm{S}$, Bie $\mathrm{Z}$, Jiang $\mathrm{H}$, Wang $\mathrm{Z}$, Jia $\mathrm{W}$, A wireless image acquisition system for artificial knee implant surgeries. 2016 IEEE 59th International Midwest Symposium on Circuits and Systems (MWSCAS); 2016 16-19 Oct.

6. Schotanus MGM, Pilot P, Vos R., Kort NP, No difference in joint awareness after mobile-and fixed-bearing total knee arthroplasty: 3-year follow-up of a randomized controlled trial. Eur $J$ Orthop Surg Traumatol., 2017; 27(8): 1151-1155.

7. Xu R, Shi D, Ge W, Jiang Q, Quantitative efficacy of topical administration of tranexamic acid on postoperative bleeding in total knee arthroplasty. Br J Clin Pharmacol., 2017; 83(11): 2485-2493.

8. Lee SH, Cho KY, Khurana S, Kim KI, Less blood loss under concomitant administration of tranexamic acid and indirect factor $\mathrm{Xa}$ inhibitor following total knee arthroplasty: a prospective randomized controlled trial. Knee Surg Sports Traumatol Arthrosc., 2013; 21(11): 2611-2617.

9. Negrei C, Caruntu C, Ginghina O, Burcea Dragomiroiu GTA, Toderescu CD, Boda D, Qualitative and quantitative determination of methotrexate polyglutamates in erythrocytes by high performance liquid chromatography. Rev Chim (Bucharest), 2015; 6(5): 607-610.

10. Karam JA, Bloomfield MR, Dilorio TM, Irizarry AM, Sharkey PF, Evaluation of the efficacy and safety of tranexamic acid for reducing blood loss in bilateral total knee arthroplasty. J Arthroplasty., 2014; 29(3): 501-503.

11. Wind TC, Barfield WR, Moskal JT, The effect of tranexamic acid on blood loss and transfusion rate in primary total knee arthroplasty. J Arthroplasty., 2013; 28(7): 1080-1083

12. Huang Z, Xie X, Li L, Huang Q, Ma J, Shen B, Kraus VB, Pei F. Intravenous and topical tranexamic acid alone are superior to tourniquet use for primary total knee arthroplasty: A prospective, randomized controlled trial. J Bone Joint Surg Am., 2017; 99(24): 2053-2061

13. Tan J, Chen H, Liu Q, Chen C, Huang W, A metaanalysis of the effectiveness and safety of using tranexamic acid in primary unilateral total knee arthroplasty. J Surg Res., 2013; 184(2): 880-887.

14. Georgiadis AG, Muh SJ, Silverton CD, Weir RM, Laker MW, A prospective double-blind placebo controlled trial of topical tranexamic acid in total knee arthroplasty. J Arthroplasty., 2013; 28(Supp18): 78-82.

15. Tarwala R, Dorr LD, Gilbert PK, Wan Z, Long WT, Tourniquet use during cementation only during total knee arthroplasty: a randomized trial. Clin Orthop Relat Res., 2014; 472(1): 169-174.

16. Gibbs V, Price A, Wall PDH, Surgical tourniquet use in total knee replacement surgery: a survey of BASK members. The Knee, 2016; 23(4): 3-4

17. Mayer C, Franz A, Harmsen J-F, Queitsch F, Behringer M, Beckmann J, Krauspe R, Zilkens C, Soft-tissue damage during total knee arthroplasty: Focus on tourniquet-induced metabolic and ionic muscle impairment. J Orthop., 2017; 14(3): 347-353

18. Aguilera X, Martinez-Zapata MJ, Bosch A, Urrutia G, Gonzalez JC, Jordan M, Gich I, Maymo RM, Martinez N, Monllau JC, Celaya F, Fernandez JA, 
Efficacy and safety of fibrin glue and tranexamic acid to prevent postoperative blood loss in total knee arthroplasty: a randomized controlled clinical trial. J Bone Joint Surg Am., 2013; 95(22): 20012007.

19. Wang JH, Chang CW, Yang CY, Chen YN, Lai $\mathrm{KA}$, Chang $\mathrm{CH}$, Intraarticular bupivacaine and epinephrine do not save blood in primary total knee arthroplasty without drains. Clin Res Orthop., $2017 ; 1: 1-5$

20. Iwai T, Tsuji S, Tomita T, Sugamoto K, Hideki Y, Hamada M, Repeat-dose intravenous tranexamic acid further decreases blood loss in total knee arthroplasty. Int Orthop., 2013; 37(3): 441-445.

21. North WT, Mehran N, Davis JJ, Silverton CD, Weir RM, Laker MW, Topical vs intravenous tranexamic acid in primary total hip arthroplasty: A double-blind, randomized controlled trial. $J$ Arthroplasty., 2016; 31(5): 1022-1026.

22. Vigna-Taglianti F, Basso L, Rolfo P, Brambilla R, Vaccari F, Lanci G, Russo R, Tranexamic acid for reducing blood transfusions in arthroplasty interventions: a cost-effective practice. Eur J Orthop Surg Traumatol., 2014; 24(4): 545-551.

23. Schiotis RE, Goșa D, Bocşan C, Suciu S, Buzoianu $\mathrm{AD}$, Particularities of treatment with conventional synthetic disease-modifying antirheumatic drugs (DMARDs) in a group of patients with rheumatoid arthritis. Farmacia, 2017; 65(3): 479-484.

24. Ottria R, Cappelletti L, Ravelli A, Mariotti M, Gigli F, Romagnoli S, Ciuffreda P, Banfi G, Drago $\mathrm{L}$, Plasma endocannabinoid behaviour in total knee and hip arthroplasty. J Biol Regul Homeost Agents., 2016; 30(4): 1147-1152.

25. Vicenti G, Pesce V, Bizzoca D, Nappi V, Palmiotto F, Carrozzo M, Moretti B, Perioperative plasmatic presepsin levels in patients undergoing total hip or knee replacement: a preliminary study. J Biol Regul Homeost Agents., 2017; 31(4): 1081-1086.

26. Demos HA, Lin ZX, Barfield WR, Wilson SH, Robertson DC, Pellegrini VD Jr, Process improvement project using tranexamic acid is cost-effective in reducing blood loss and transfusions after total hip and total knee arthroplasty. J Arthroplasty., 2017; 32(8): 2375-2380. 